\title{
Adoption Level of Animal Husbandry Practices in Haryana, India
}

\author{
Anil Kumar Rohila ${ }^{1 *}$, P.S. Shehrawat ${ }^{1}$ and Aditya $^{2}$ \\ ${ }^{1}$ Department of Extension Education, ${ }^{2}$ College of Agriculture, CCS Haryana Agricultural \\ University, Hisar-125004, India \\ *Corresponding author
}

A B S T R A C T

Keywords

Adoption, Breeding, Feeding, Health and Practices

Article Info

Accepted:

07 March 2018

Available Online:

10 April 2018
Present study was conducted in Haryana to find out adoption level of animal husbandry practices in Haryana. The data were collected with the help of well-structured and pretested interview schedule and analyzed through computer software Statistical Package for Social Sciences (SPSS) for tabulating results and drawing conclusions and recommendations. Present study concluded that adoption level was high about allow the animal to mate within 3 months after parturition $(67.41 \%)$, mineral mixture (76.85\%), protect the animals from harsh weather conditions (77.78\%), disinfect the udder before milking (100.00\%), and proper ventilated house for animals $(72.59 \%)$. Study also concluded that 43.00 per cent variation in the adoption of the respondents regarding smart animal practices when other factors were kept constant.

\section{Introduction}

Dairying is a main occupation in rural India and provides employment and income. Now a day dairy farming has become a commercial enterprise and helps the farmers to improve their economic condition.

Milk production has been estimated to be increased by 6.4 per cent in 2016-17 over 2015-16. While, in case of seasonal estimation, the total milk production has increased from 51.33 Million Tonnes during 2016-17 (Summer) to 53.77 Million Tonnes during 2017-18 (Summer) with the growth rate of 4.7 per cent (Annonymous, 2018). The Government of India (GOI) estimated demand for milk to increase to 200 million metric tons (MMT) by the year 2021-22, requiring a 20 per cent increase in milk production.

So, Government of India has implemented the National Dairy Plan (NDP) through the National Dairy, Milk, Nonfat Dry Dairy, Milk, Fluid Dairy, Butter Dairy Development Board (NDDB) which focuses on breed/genetic improvement, artificial insemination, fodder development and expansion of milk procurement systems at the village level (Annonymous, 2017). 
Keeping these factors in mind, the present investigation was planned to identify the adoption level of animal husbandry practices in Haryana state of India.

\section{Materials and Methods}

The study was conducted in Haryana state in 2017. Two districts viz. Hisar from SouthWest Zone and Kaithal from North-East Zone were selected, purposively. Further, three villages from each district were selected, randomly.

Thus, six villages namely, Ladwa, Shahrwa and Rawalwas Khurd villages from Hisar, while, Kaul, Rasina and Bhana villages from Kaithal were selected, randomly. Further, thirty farmers were selected, randomly from each selected village. Thus, a total number of 180 respondents were interviewed for the present study.

A schedule was developed to measure the adoption level after paid a deep discussion with advisory committee, experts and professionals. Available research based literature were also reviewed for the preparation of the interview schedule. The responses of farmers were obtained on threepoint continuum scale as full adoption', 'partial adoption' and 'no adoption' and weightage were given as 3,2 and 1 , respectively. Aggregate total weightage score was calculated for each statement separately and on the basis of calculated score, total weighted score and weighted mean score were obtained. Further, rank orders were assigned based on the weighted mean score.

Adoption index was calculated with the following formula:

Total obtained adoption score Adoption Index (A.I.) = ------------------- ×100

Maximum possible obtained adoption score

\section{Results and Discussion}

\section{Breeding}

It is clear from Table 1 that practice about 'allow the animal to mate within 3 months after parturition' ranked $1^{\text {st }}$ with highest adoption index (A.I.) 67.41 per cent, followed by 'animal checkup time to time during pregnancy' $(64.44 \%)$, 'diagnosis of your animal for pregnancy' $(64.07 \%)$, and 'artificial insemination (A.I.) practices' $(55.74 \%)$ ranked $2^{\text {nd }}, 3^{\text {rd }}$ and $4^{\text {th }}$, respectively. However, 'artificial insemination (A.I.) within 12 hours after detection of heat' ranked $5^{\text {th }}$ with lowest adoption index. It was further revealed from research findings that farmers with less land holding had low level of adoption in buffalo husbandry practices. The extension agencies in study area need to take immediate initiatives to take up extension programs to enhance the farmers' awareness or knowledge level about the dairy farmers about breeding practices. Sharma and Singh (2011) and Sachan et al., (2016) reported similar findings.

\section{Feeding}

Data presented in Table 2 showed that 'mineral mixture' was highly adopted, followed by 'colostrums to new born calves up to 3-5 days after its birth' (66.30\%) and 'green fodder to the animal regularly' $(66.30 \%)$ both were ranked $2^{\text {nd }}$. While, 'to feed extra $1-2 \mathrm{~kg}$ concentrate to pregnant animal' $(65.37 \%)$ and 'to feed concentrate mixture on the basis of milk production' $(63.89 \%)$ ranked $3^{\text {rd }}$ and $4^{\text {th }}$, respectively. Adoption of feeding practices can be increased through mass media and training programs at village level in collaboration of village panchayat. These finding were found to be partially support by reports of Aulakh et al., (2011); Kumawat and Verma (2016) and Minhaj et al., (2017). 
Table.1 Breeding

\begin{tabular}{|c|c|c|c|c|c|c|c|c|}
\hline \multicolumn{9}{|c|}{$(n=180)$} \\
\hline $\begin{array}{l}\text { S. } \\
\text { No. }\end{array}$ & Practices & $\begin{array}{l}\text { Fully } \\
\text { Adopted } \\
(\%)\end{array}$ & $\begin{array}{l}\text { Partially } \\
\text { Adopted } \\
(\%)\end{array}$ & $\begin{array}{c}\text { Not } \\
\text { Adopted } \\
(\%)\end{array}$ & $\begin{array}{l}\text { Total } \\
\text { Weighted } \\
\text { Score }\end{array}$ & $\begin{array}{l}\text { Weighted } \\
\text { Mean Score }\end{array}$ & $\begin{array}{l}\text { Adoption in } \\
\%\end{array}$ & $\begin{array}{l}\text { Rank } \\
\text { Order }\end{array}$ \\
\hline 1 & $\begin{array}{l}\text { Artificial insemination (A.I.) } \\
\text { practices }\end{array}$ & $\begin{array}{c}3 \\
(1.67)\end{array}$ & $\begin{array}{c}115 \\
(63.89)\end{array}$ & $\begin{array}{c}62 \\
(34.44)\end{array}$ & 301 & 1.67 & 55.74 & IV \\
\hline 2 & $\begin{array}{l}\text { Artificial insemination (A.I.) } \\
\text { within } 12 \text { hours after detection } \\
\text { of heat }\end{array}$ & $\begin{array}{c}4 \\
(2.22)\end{array}$ & $\begin{array}{c}111 \\
(61.67)\end{array}$ & $\begin{array}{c}65 \\
(36.11)\end{array}$ & 299 & 1.66 & 55.37 & V \\
\hline 3 & $\begin{array}{l}\text { Allow the animal to mate } \\
\text { within } 3 \text { months after } \\
\text { parturition }\end{array}$ & $\begin{array}{c}14 \\
(7.78)\end{array}$ & $\begin{array}{c}156 \\
(86.67)\end{array}$ & $\begin{array}{c}10 \\
(5.55)\end{array}$ & 364 & 2.02 & 67.41 & I \\
\hline 4 & $\begin{array}{l}\text { Diagnosis of your animal for } \\
\text { pregnancy }\end{array}$ & $\begin{array}{c}10 \\
(5.56)\end{array}$ & $\begin{array}{c}146 \\
(81.11)\end{array}$ & $\begin{array}{c}24 \\
(13.33)\end{array}$ & 346 & 1.92 & 64.07 & III \\
\hline 5 & $\begin{array}{l}\text { Animal checkup time to time } \\
\text { during pregnancy }\end{array}$ & $\begin{array}{c}9 \\
(5.00)\end{array}$ & $\begin{array}{c}150 \\
(83.33)\end{array}$ & $\begin{array}{c}21 \\
(11.67)\end{array}$ & 348 & 1.93 & 64.44 & II \\
\hline
\end{tabular}

Table.2 Feeding

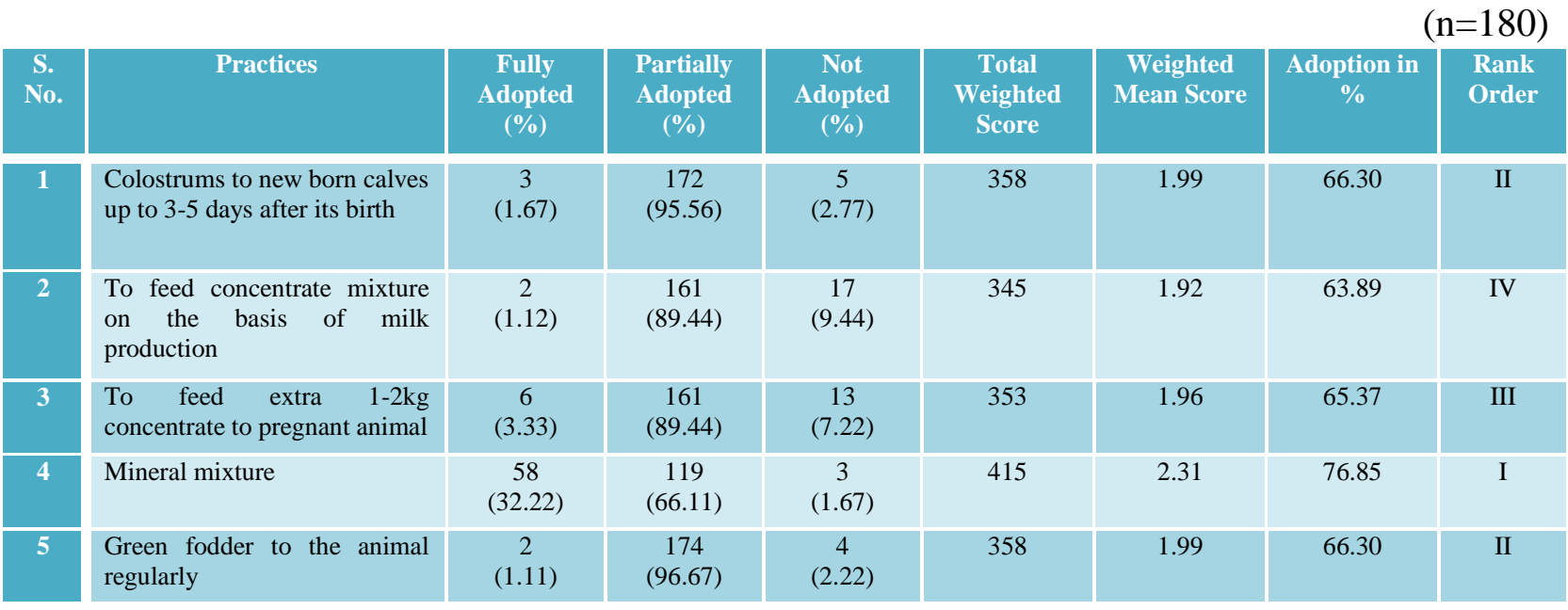

Table.3 Health care

\begin{tabular}{|c|c|c|c|c|c|c|c|c|}
\hline S. No. & Practices & $\begin{array}{c}\text { Fully } \\
\text { Adopted } \\
(\%)\end{array}$ & $\begin{array}{l}\text { Partially } \\
\text { Adopted } \\
(\%)\end{array}$ & $\begin{array}{c}\text { Not } \\
\text { Adopted } \\
(\%)\end{array}$ & $\begin{array}{c}\text { Total } \\
\text { Weighted } \\
\text { Score }\end{array}$ & $\begin{array}{l}\text { Weighted } \\
\text { Mean Score }\end{array}$ & $\begin{array}{c}\text { Adoption in } \\
\%\end{array}$ & $\begin{array}{l}\text { Rank } \\
\text { Order }\end{array}$ \\
\hline 1 & $\begin{array}{l}\text { Protect the animals } \\
\text { from harsh weather } \\
\text { conditions }\end{array}$ & $\begin{array}{c}62 \\
(34.44)\end{array}$ & $\begin{array}{c}116 \\
(64.44)\end{array}$ & $\begin{array}{c}2 \\
(1.12)\end{array}$ & 420 & 2.33 & 77.78 & I \\
\hline 3 & $\begin{array}{l}\text { Deworm the animals } \\
\text { timely against ecto } \\
\text { and endo parasites }\end{array}$ & $\begin{array}{c}7 \\
(3.89)\end{array}$ & $\begin{array}{c}168 \\
(93.33)\end{array}$ & $\begin{array}{c}5 \\
(2.77)\end{array}$ & 362 & 2.01 & 67.04 & III \\
\hline 4 & $\begin{array}{l}\text { Segregate the } \\
\text { diseased animals } \\
\text { from the herd }\end{array}$ & $\begin{array}{c}4 \\
(2.22)\end{array}$ & $\begin{array}{c}46 \\
(25.56)\end{array}$ & $\begin{array}{c}130 \\
(72.22)\end{array}$ & 234 & 1.30 & 43.33 & V \\
\hline 5 & $\begin{array}{l}\text { Regularly consults } \\
\text { the veterinary } \\
\text { doctor/VLDA }\end{array}$ & $\begin{array}{c}14 \\
(7.78)\end{array}$ & $\begin{array}{c}89 \\
(49.44)\end{array}$ & $\begin{array}{c}77 \\
(42.78)\end{array}$ & 297 & 1.65 & 55.00 & IV \\
\hline
\end{tabular}


Table.4 Milk production

\begin{tabular}{|c|c|c|c|c|c|c|c|c|}
\hline $\begin{array}{l}\text { S. } \\
\text { No. }\end{array}$ & Practices & $\begin{array}{c}\text { Fully } \\
\text { Adopted } \\
(\%)\end{array}$ & $\begin{array}{l}\text { Partially } \\
\text { Adopted } \\
(\%)\end{array}$ & $\begin{array}{c}\text { Not } \\
\text { Adopted } \\
(\%)\end{array}$ & $\begin{array}{l}\text { Total } \\
\text { Weighted } \\
\text { Score } \\
\end{array}$ & $\begin{array}{l}\text { Weighted } \\
\text { Mean Score }\end{array}$ & $\begin{array}{l}\text { Adoption in } \\
\%\end{array}$ & $\begin{array}{l}\text { Rank } \\
\text { Order }\end{array}$ \\
\hline 1 & $\begin{array}{l}\text { Wash the animal before } \\
\text { milking }\end{array}$ & $\begin{array}{c}11 \\
(6.11)\end{array}$ & $\begin{array}{c}169 \\
(93.89)\end{array}$ & $\begin{array}{c}0 \\
(0.00)\end{array}$ & 371 & 2.06 & 68.70 & III \\
\hline 2 & $\begin{array}{l}\text { Disinfect the udder } \\
\text { before milking }\end{array}$ & $\begin{array}{c}180 \\
(100.00)\end{array}$ & $\begin{array}{c}0 \\
(0.00)\end{array}$ & $\begin{array}{c}0 \\
(0.00)\end{array}$ & 540 & 3.00 & 100.00 & I \\
\hline 3 & $\begin{array}{l}\text { Full hand method for } \\
\text { milking }\end{array}$ & $\begin{array}{c}0 \\
(0.00)\end{array}$ & $\begin{array}{c}15 \\
(8.33)\end{array}$ & $\begin{array}{c}165 \\
(91.67)\end{array}$ & 195 & 1.08 & 36.11 & IV \\
\hline 4 & $\begin{array}{l}\text { Clean the utensils with } \\
\text { boiled water/detergent } \\
\text { before milking }\end{array}$ & $\begin{array}{c}95 \\
(52.78)\end{array}$ & $\begin{array}{c}85 \\
(47.22)\end{array}$ & $\begin{array}{c}0 \\
(0.00)\end{array}$ & 455 & 2.53 & 84.26 & II \\
\hline 5 & Use of $\mathrm{KMnO}_{4}$ & $\begin{array}{c}0 \\
(0.00)\end{array}$ & $\begin{array}{c}6 \\
(3.33)\end{array}$ & $\begin{array}{c}174 \\
(96.67)\end{array}$ & 186 & 1.03 & 34.44 & V \\
\hline
\end{tabular}

Table.5 General management practices

$(n=180)$

\begin{tabular}{|c|c|c|c|c|c|c|c|c|}
\hline S. No. & Practices & $\begin{array}{l}\text { Fully } \\
\text { Adopted } \\
(\%)\end{array}$ & $\begin{array}{l}\text { Partially } \\
\text { Adopted } \\
(\%)\end{array}$ & $\begin{array}{c}\text { Not } \\
\text { Adopted } \\
(\%)\end{array}$ & $\begin{array}{l}\text { Total } \\
\text { Weighted } \\
\text { Score }\end{array}$ & $\begin{array}{l}\text { Weighted } \\
\text { Mean Score }\end{array}$ & $\begin{array}{c}\text { Adoption in } \\
\%\end{array}$ & $\begin{array}{l}\text { Rank } \\
\text { Order }\end{array}$ \\
\hline 1 & $\begin{array}{l}\text { Adequate open } \\
\text { space to the animals }\end{array}$ & $\begin{array}{c}32 \\
(17.78)\end{array}$ & $\begin{array}{c}147 \\
(81.67)\end{array}$ & $\begin{array}{c}1 \\
(0.55)\end{array}$ & 391 & 2.17 & 72.41 & II \\
\hline 2 & $\begin{array}{l}\text { Proper ventilated } \\
\text { house for animals }\end{array}$ & $\begin{array}{c}34 \\
(18.89)\end{array}$ & $\begin{array}{c}144 \\
(80.00)\end{array}$ & $\begin{array}{c}2 \\
(1.11)\end{array}$ & 392 & 2.18 & 72.59 & I \\
\hline 3 & $\begin{array}{l}\text { Proper water and } \\
\text { feed to the animals }\end{array}$ & $\begin{array}{c}14 \\
(7.78)\end{array}$ & $\begin{array}{c}164 \\
(91.11\end{array}$ & $\begin{array}{c}2 \\
(1.11)\end{array}$ & 372 & 2.07 & 68.89 & III \\
\hline 4 & $\begin{array}{l}\text { Segregate the } \\
\text { pregnant animals } \\
\text { from herd }\end{array}$ & $\begin{array}{c}0 \\
(0.00)\end{array}$ & $\begin{array}{c}25 \\
(13.89)\end{array}$ & $\begin{array}{c}155 \\
(86.11)\end{array}$ & 205 & 1.14 & 37.96 & V \\
\hline 5 & $\begin{array}{l}\text { Exercise and } \\
\text { grooming }\end{array}$ & $\begin{array}{c}5 \\
(2.78)\end{array}$ & $\begin{array}{c}164 \\
(91.11)\end{array}$ & $\begin{array}{c}11 \\
(6.11)\end{array}$ & 354 & 1.97 & 65.56 & IV \\
\hline
\end{tabular}

Fig.1 Relationship of adoption level of farmers' with their personality traits

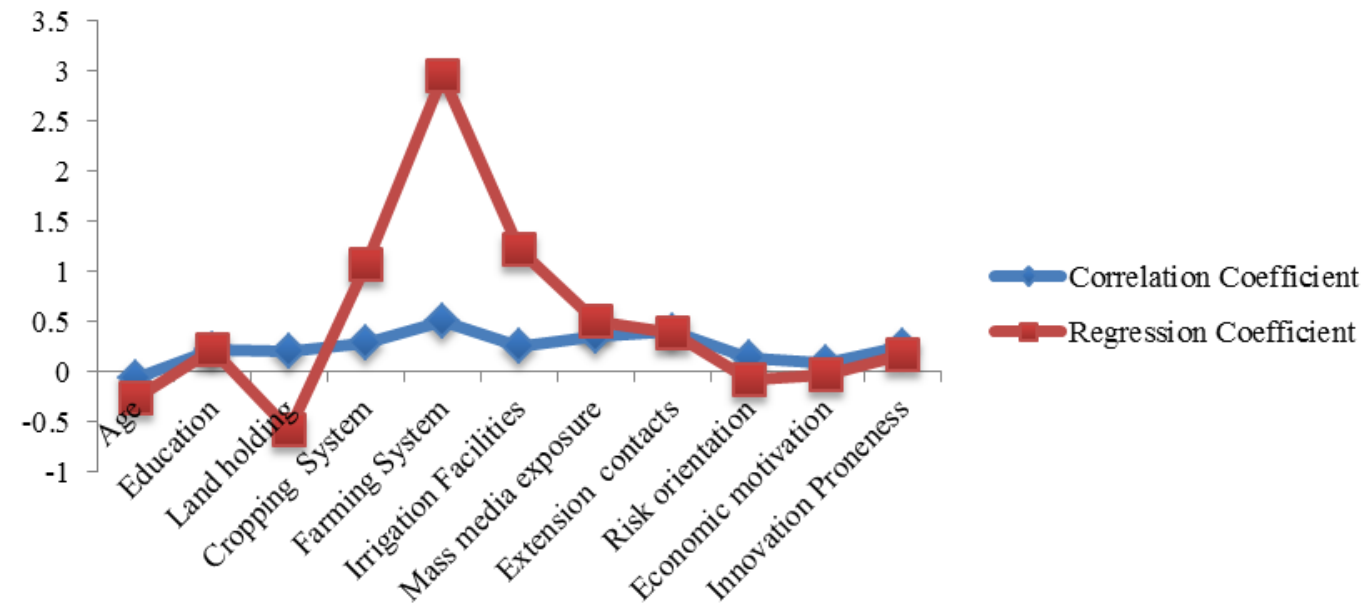

Dependent variable- Adoption

*Significant at 0.05 levels

$\mathrm{R}^{2}=0.43$, Constant Value $=39.07$ 


\section{Health cares}

Table 3 revealed that majority of farmers' adopted the practice about 'protect the animals from harsh weather conditions' ranked $1^{\text {st }}$ with highest adoption index (A.I.) 77.78 per cent, followed by 'proper vaccination schedule' $(68.33 \%)$, 'deworm the animals timely against ecto and endo parasites' (67.04\%), and 'regularly consults the veterinary doctor/VLDA' $(55.00 \%)$ ranked $2^{\text {nd }}, 3^{\text {rd }}$ and $4^{\text {th }}$, respectively. While, adoption level was low about 'segregate the diseased animals from the herd' ranked $5^{\text {th }}$ with lowest A.I. 43.33 per cent. Animal production is totally depends on health of animals so there is need to improve the diffusion of health care practices among farmers' to be optimize their production and enhance overall farm income. Chander et al., (2015) concluded that there was lack of awareness about deworming. While, Sachan et al., (2016) who reported that majority of the farmers had medium adoption level of health care practices.

\section{Milk production}

The data presented in Table 4 showed that practice about 'disinfect the udder before milking' was highly adopted with adoption index 100.00 per cent, followed by 'clean the utensils with boiled water/detergent before milking' (84.26\%), 'wash the animal before milking' $(68.70 \%)$, 'full hand method for milking' $(36.11 \%)$ ranked $2^{\text {nd }}, 3^{\text {rd }}$ and $4^{\text {th }}$, respectively.

However, adoption was very poor about 'use of $\mathrm{KMnO}_{4}$ '. Adoption regarding milk production can be increased through frequent contact with the dairy farmers and make them aware about these scientific dairy farming practices. These finding were found to partially support by findings of Sachan et al., (2016).

\section{General management practices}

Table 5 narrated that 'proper ventilated house for animals' ranked $1^{\text {st }}$ with highest adoption index (A.I.) 72.59 per cent, followed by 'adequate open space to the animals' (72.41\%), 'proper water and feed to the animals' (68.89\%), 'exercise and grooming' $(65.56 \%)$, and 'segregate the pregnant animals from herd' $(37.96 \%)$ ranked $2^{\text {nd }}, 3^{\text {rd }}$, $4^{\text {th }}$ and $5^{\text {th }}$, respectively.

Study got strength from past research study of Sharma and Singh (2011) and Sachan et al., (2016) who reported that majority of farmers had medium adoption level of these management practices.

\section{Relationship of adoption level of farmers' with their personality traits}

Figure 1 revealed that education, land holding, cropping system, farming system, irrigation facilities, mass media exposure, extension contacts, risk orientation and innovation proneness with the adoption level had positive and significant correlation at 0.05 level of probability. While in case of the partial regression coefficient land holding, cropping system, farming system, irrigation facilities, mass media exposure and innovation proneness were found to be significant. These finding were found to be partially support by report of Yadav et al., (2013).

Further, it is revealed that all the eleven independent variables included in the study jointly contributed 43.00 per cent variation in the adoption of the respondents regarding smart animal practices when other factors were kept constant. This means that only 43.00 per cent of the variation in the dependent variable was due to these variables and remaining 57.00 per cent variations is due to other variables. 
The present study concluded that overall adoption level was medium. Therefore, scientists, KVK's, veterinary officers, SAU's should be organized training and awareness programmes with respect to breeding, feeding, health care, milk production and management practices and motivate them to boost up level of adoption of animal husbandry practices.

\section{References}

Annonymous, 2017. Global Agricultural Information Network (GAIN) Report No. IN7123.

Annonymous, 2018. Press Information Bureau, Ministry of Agriculture \& Farmers Welfare, Government of India. 16 January 2018.

Aulakh, G.S., Singh, R. and Yadav, J.S. (2011). A study on adoption of recommended feeding practices by the buffalo owners of Punjab. Indian Journal of Animal Sciences. Vol. 81(6): 631-633.

Chander, M., Meena, H.R., Tripathi, H., Kumar, S., Rathore, R.S., Banerji, P.S., Pachaiyappan, K. and Rathod, P. 2015. Diffusion and Adoption of Livestock Deworming Technology in Different Agro-climatic Regions of India. Indian
Journal of Extension Education. 51(3\&4): 101-103.

Kumawat, S.R. and Verma, M.P. 2016. Adoption of Dairy Farming Technologies by the Farmers of Nagaur District of Rajasthan. Indian Journal of Extension Education. 52 (3\&4): 160163.

Minhaj, S.U., Khandi, S.A., Bafanda, R.A., and Bhushan, B. 2017. Adoption of Improved Animal Husbandry Practices by dairy farmers of Doda district of Jammu and Kashmir, India. International Journal of Current Microbiology and Applied Science. 6(12): 2703-2707.

Sachan, R., Sankhala, G., Roy, R. and Manjusha, J. 2016. Adoption level of recommended buffalo husbandry practices by dairy farmers in Uttar Pradesh. Indian Journal Dairy Science. 69(5): 613-617.

Sharma, K. and Singh, S.P. (2011). Adoption of dairy farmers regarding breeding and management practices of buffalo husbandry. Indian Journal of Extension Education. 47(1 \& 2): 55-62.

Yadav, B.C., Choudhary, R. and Saran, P.L. 2013. Adoption of improved production technology of mandarin in Rajasthan, India: A review. African Journal of Agricultural Research. 8(49): 65906600.

\section{How to cite this article:}

Anil Kumar Rohila, P.S. Shehrawat and Aditya. 2018. Adoption Level of Animal Husbandry Practices in Haryana, India. Int.J.Curr.Microbiol.App.Sci. 7(04): 563-568. doi: https://doi.org/10.20546/ijcmas.2018.704.066 